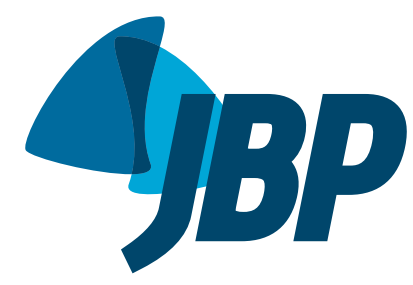

1. Programa de Pós-Graduação em Ciências Pneumológicas, Universidade Federal do Rio Grande do Sul - UFRGS - Porto Alegre (RS) Brasil.

2. Laboratório de Vias Aéreas e Pulmão, Hospital de Clínicas de Porto Alegre HCPA - Universidade Federal do Rio Grande do Sul - UFRGS - Porto Alegre (RS) Brasil.

3. Serviço de Nutrição, Hospital de Clínicas de Porto Alegre - HCPA - Universidade Federal do Rio Grande do Sul - UFRGS - Porto Alegre (RS) Brasil.

4. Serviço de Pneumologia, Hospital de Clínicas de Porto Alegre - HCPA Universidade Federal do Rio Grande do Sul - UFRGS - Porto Alegre (RS) Brasil.

Submitted: 27 October 2016

Accepted: 26 February 2017.

Study carried out at the Hospital de Clínicas de Porto Alegre - HCPA -

Universidade Federal do Rio Grande do Sul - UFRGS - Porto Alegre (RS) Brasil.

\section{Factors associated with malnutrition in adolescent and adult patients with cystic fibrosis}

\author{
Gabriela Cristofoli Barni1, Gabriele Carra Forte1, Luis Felipe Forgiarini1,2,
} Claudine Lacerda de Oliveira Abrahão ${ }^{3}$, Paulo de Tarso Roth Dalcin ${ }^{1,4}$

\begin{abstract}
Objective: To determine the prevalence of malnutrition in patients attending an adult cystic fibrosis (CF) program and to investigate the associations of malnutrition with the clinical characteristics of those patients. Methods: This was a cross-sectional study involving patients with clinically stable CF patients (16 years of age or older). The patients underwent clinical assessment, nutritional assessments, pulmonary function tests, and pancreatic function assessment. They also completed a questionnaire regarding diet compliance. On the basis of their nutritional status, the patients were classified divided into three groups: adequate nutrition; at nutritional risk; and malnutrition. Results: The study has included 73 patients (mean age, $25.6 \pm 7.3$ years), 40 of whom (54.8\%) were female. The mean body mass index was $21.0 \pm 3.0 \mathrm{~kg} / \mathrm{m}^{2}$ and the mean FEV was 59.7 $\pm 30.6 \%$ of predicted. In this sample of patients, $32(43.8 \%), 23(31.5 \%)$, and $18(24.7 \%)$ of the patients were allocated to the adequate nutrition, nutritional risk, and malnutrition groups, respectively. The logistic regression analysis identified three independent factors associated with the risk of malnutrition: Shwachman-Kulczycki score, percent predicted $\mathrm{FEV}_{1}$; and age. Conclusions: Malnutrition remains a common complication in adolescents and adults with CF, despite dietary advice. Malnutrition is associated with age, clinical severity, and lung function impairment.
\end{abstract}

Keywords: Cystic fibrosis; Malnutrition; Exocrine pancreatic insufficiency; Respiratory function tests.

\section{INTRODUCTION}

Cystic fibrosis (CF) is the most common life-limiting autosomal recessive disease in caucasians, and it is caused by the absence or dysfunction of the cystic fibrosis transmembrane conductance regulator (CFTR) protein. Mutations in the CFTR gene are known to alter the airway and the intestinal microenvironment. ${ }^{(1,2)}$ This protein is expressed as a chloride channel in the apical membrane of airway cells, as well as in intestine, liver, and reproductive tissues; it affects exocrine pancreatic function and sweat ducts. The CFTR protein regulates and participates in the electrolyte transport across the membranes of those cells. Thus, its absence or partial functioning is related to the pathophysiology of CF. $(3,4)$

The clinical manifestations of the disease result from an increased viscosity of secretions, which leads to the obstruction of ductal epithelial cells. The classic phenotype of the $\mathrm{CF}$, or mucoviscidosis, is characterized by pulmonary infections, pancreatic insufficiency, malabsorption of nutrients, liver disease, male infertility, and loss of sweat electrolytes. ${ }^{(5)}$

In recent years, medical and technological advances have increased the mean survival rates worldwide, primarily through the early diagnosis of $\mathrm{CF}_{\text {, input of }}$ experts, better treatments, and organ transplantations. Nearly half of the CF population is $\geq 18$ years of age. ${ }^{(5)}$

The clinical course of CF and the quality of life of the patients are directly affected by their nutritional status, and malnutrition is one of the most serious and difficult challenges in CF treatment. ${ }^{(6)}$ Malnutrition results from a discrepancy between energy/nutrient requirements and food intake, which can be caused by malabsorption. ${ }^{(7)}$

Malnutrition and lung disease are inextricably woven together in CF. Studies have shown that lung function decline and malnutrition are related and are dependent factors. The occurrence of malnutrition is associated with reductions in lung function and survival. Chronic pulmonary infections and decreased lung function result in increased calorie needs and reduced appetite, which worsen the nutritional status of CF patients. ${ }^{(8,9)}$ There is a growing body of literature looking at malnutrition and CF; however, those studies are mostly related to pediatric patients. $(10,11)$

The aims of the present study were to determine the prevalence of malnutrition in patients attending an adult CF program and to investigate the associations of malnutrition with the clinical characteristics of those patients.

Correspondence to:

Gabriela Cristofoli Barni. Rua João Berutti, 492, Chácara das Pedras, CEP 91330-370, Porto Alegre, RS, Brasil.

Tel.: 5551 9191-9307. E-mail: gabicbarni@hotmail.com

Financial support: This study received financial support from the Fundo de Incentivo à Pesquisa do Hospital de Clinicas de Porto Alegre (FIPE-HCPA, Research Incentive Fund of the Porto Alegre Hospital de Clínicas). Gabriela Cristofoli Barni is the recipient of a grant from the Coordenação de Aperfeiçoamento de Pessoal de Nive/ Superior (CAPES, Office for the Advancement of Higher Education). 


\section{METHODS}

\section{Study design}

This was a single-center, cross-sectional study of prospectively collected data, and it was approved by the Research Ethics Committee of the Hospital de Clínicas de Porto Alegre, located in the city of Porto Alegre, Brazil. All of the subjects gave written informed consent.

\section{Population}

The study included patients with CF who were 16 years of age or older. We included only CF patients who had been diagnosed on the basis of consensus criteria.(12) All patients had to be clinically stable in order to be included in the study, clinical stability being defined as no current changes in medications and no use of i.v. or p.o. antibiotics due to pulmonary exacerbations in the last 30 days. Patients were excluded if they declined to participate in the study, did not meet the inclusion criteria, or were pregnant.

\section{Clinical variables}

The following data were recorded: age, gender, ethnicity, presence of the F508del mutation (homozygous, heterozygous, or other mutations), presence of diabetes mellitus, and a liver score (normal or abnormal). ${ }^{(13)}$

\section{Nutritional evaluation}

Nutritional status was assessed using the body mass index (BMI) and its percentile. BMI was calculated from the ratio weight/height ${ }^{2}\left(\mathrm{~kg} / \mathrm{m}^{2}\right)$. Patients younger than 20 years of age had their BMI percentile calculated. On the basis of their nutritional status, the patients were divided into three groups: adequate nutrition (AN): BMI > $22 \mathrm{~kg} / \mathrm{m}^{2}$ for women and BMI $>23 \mathrm{~kg} /$ $\mathrm{m}^{2}$ for men (for patients $\geq 20$ years of age) or BMI percentile $>25$ (for patients $<20$ years of age); at nutritional risk (NR): BMI $=19-22 \mathrm{~kg} / \mathrm{m}^{2}$ for women and $19-23 \mathrm{~kg} / \mathrm{m}^{2}$ for men (for patients $\geq 20$ years of age) or BMI percentile $=10-25$ (for patients $<20$ years of age); and malnutrition (MN): BMI $<19 \mathrm{~kg} /$ $\mathrm{m}^{2}$ (for patients $\geq 20$ years of age) or BMI percentile $<10$ (for patients $<20$ years of age). ${ }^{(6,14)}$

\section{Bacteriological status}

Bacterial isolates from sputum cultures of the participants were assessed in the Microbiology Department of the Hospital de Clínicas de Porto Alegre. The presence of Staphylococcus aureus, Pseudomonas aeruginosa, and Burkholderia cepacia was registered. The presence of any of the aforementioned pathogens was confirmed by their isolation from routine sputum samples in the laboratory on at least two occasions, at least 12 months apart.

\section{Clinical score}

The clinical score used was the Shwachman-Kulczycki (S-K) score, ${ }^{(15)}$ assessed by the physician of the CF team at an outpatient setting.

\section{Pulmonary function tests}

Pulmonary function tests were performed with a computerized spirometer (MasterScreen v4.31; Jaeger, Würzburg, Germany). At least three curves were obtained, the best ones being selected, for the determination of FVC and $\mathrm{FEV}_{1}$, both in $\mathrm{L}$ and percentage of predicted values for age, stature, and gender. ${ }^{(16)}$

\section{Assessment of pancreatic function}

The fecal elastase- 1 test was performed using monoclonal ELISA. Stool samples were collected and stored at a temperature of $-22^{\circ} \mathrm{C}$ until being tested. The cut-off point of $200 \mu \mathrm{g} / \mathrm{g}$ was used in order to classify the exocrine pancreatic function of the patients ( $\geq 200 \mu \mathrm{g} / \mathrm{g}$ : sufficiency; < $200 \mu \mathrm{g} / \mathrm{g}$ : insufficiency). Patients whose results were $\geq 100 \mu \mathrm{g} / \mathrm{g}$ but $<200$ $\mu \mathrm{g} / \mathrm{g}$ were classified as having moderate exocrine pancreatic insufficiency. Patients with elastase- 1 levels $<100 \mu \mathrm{g} / \mathrm{g}$ were classified as having severe exocrine pancreatic insufficiency. ${ }^{(17)}$

\section{Compliance with dietary treatment}

Patients were asked to complete a questionnaire (adapted from another study) ${ }^{(18)}$ with three questions about their compliance with pancreatic enzyme replacement therapy, multivitamin supplement (vitamins $A, D, E$, and $K$ ) intake, and a hypercaloric diet (a diet high in energy, protein, and fat, based on a nutritional care plan and tailored to meet the nutritional requirements of each individual). Each question was to be answered on the basis of their weekly frequency of intake, as follows: a) every day or almost every day; b) 3-5 days a week; c) less than 3 days a week or never; and d) not applicable.

\section{Statistical analysis}

All data were processed and analyzed using the Statistical Package for the Social Sciences, version 18.0 (SPSS Inc., Chicago, IL, USA). Quantitative results were expressed as means and standard deviations or as medians and interquartile ranges, whereas qualitative variables were expressed as numbers of cases and proportions. Quantitative data with normal distribution were subjected to one-way ANOVA with Tukey's post hoc test. For continuous data with nonnormal distribution, the Kruskal-Wallis test and the post hoc $Z$ test were used. The chi-square test was applied to all qualitative data, as was Yates' correction or Fisher's exact test, as required. Multivariate analyses were generated through logistic regression analysis using the enter method. On this basis, the odds ratio was the odds ratio for malnutrition. Selected variables with $p<0.10$ were introduced in the binary logistic regression controlled by gender and age. ROC curves were then created for each predictor variable identified in the logistic regression analysis and used to calculate the sensitivity, specificity, and predictive values of the clinical variables related to malnutrition. All statistical tests used were two-tailed. The level of significance was set at $p<0.05$. 


\section{RESULTS}

In the period between May of 2013 and May of 2014, 104 patients were invited to participate in the study. Of these, 6 patients died before all the tests were completed, 1 moved to another country, 6 declined to participate, and 18 patients did not perform the fecal elastase- 1 test; therefore, the total sample comprised 73 patients who completed the study. The result of the fecal elastase- 1 test was inconclusive for 7 patients (of 66 patients), although the test was run twice. The mean age of the subjects was $25.6 \pm 7.3$ years (19 adolescents and 54 adults), 40 (54.8\%) of whom were females and 33 (45.2\%) of whom were males. All subjects were White. The mean BMI was $21.0 \pm$ $3.0 \mathrm{~kg} / \mathrm{m}^{2}$, and the mean $\mathrm{FEV}_{1}$ was $59.7 \pm 30.6 \%$ of the predicted value. Groups were formed on the basis of the nutritional status of the patients: AN group ( $\mathrm{n}$ $=32 ; 43.8 \%)$; NR group $(n=23 ; 31.5 \%)$; and $M N$ group ( $n=18 ; 24.7 \%$; Table 1 ).

Table 2 presents a comparison of the clinical characteristics among the aforementioned groups. There were no significant differences among the

Table 1. Clinical characteristics of the patients included in the study $(\mathrm{N}=73)$. $^{\text {a }}$

\begin{tabular}{|c|c|}
\hline Variable & Result \\
\hline \multicolumn{2}{|l|}{ Gender } \\
\hline Male & $33(45.2)$ \\
\hline Female & $40(54.8)$ \\
\hline Age, years & $25.6 \pm 7.3$ \\
\hline $\mathrm{BMI}, \mathrm{kg} / \mathrm{m}^{2}$ & $21.0 \pm 3.0$ \\
\hline \multicolumn{2}{|l|}{ Nutritional classification } \\
\hline Adequate nutrition & $32(43.8)$ \\
\hline Nutritional risk & $23(31.5)$ \\
\hline Malnutrition & $18(24.7)$ \\
\hline CFRD & $10(13.7)$ \\
\hline \multicolumn{2}{|l|}{ Type of mutation } \\
\hline Homozygous for F508del & $13(17.8)$ \\
\hline Heterozygous for F508del & $33(45.2)$ \\
\hline Other/unidentified mutations & $27(37.0)$ \\
\hline Age at diagnosis, years ${ }^{b}$ & $8(16)$ \\
\hline S-K score & $70.41 \pm 16.4$ \\
\hline \multicolumn{2}{|l|}{ Lung function } \\
\hline FVC, L & $3.0 \pm 1.24$ \\
\hline FVC, \% predicted & $71.3 \pm 31.5$ \\
\hline $\mathrm{FEV}_{1}, \mathrm{~L}$ & $2.1 \pm 1.1$ \\
\hline $\mathrm{FEV}_{1}, \%$ predicted & $59.7 \pm 30.6$ \\
\hline Fecal elastase-1, $\mu \mathrm{g} / \mathrm{g}$ & $92.3 \pm 36.8$ \\
\hline \multicolumn{2}{|l|}{ Bacterial colonization } \\
\hline Pseudomonas aeruginosa & $48(65.8)$ \\
\hline Staphylococcus aureus & $50(68.5)$ \\
\hline MRSA & $8(11.0)$ \\
\hline Burkholderia cepacia & $15(20.5)$ \\
\hline
\end{tabular}

BMI: body mass index; S-K: Shwachman-Kulczycki; CFRD: cystic fibrosis-related diabetes; and MRSA: methicillin-resistant Staphylococcus aureus. aValues expressed as $n(\%)$ or mean $\pm S D$, except where otherwise indicated. 'Value expressed as median (interquartile range). groups regarding gender, age, presence of F508del mutation, and liver score. The proportion of patients with diabetes mellitus was significantly higher in the NR group than in the AN and MN groups ( $p=0.014$ ). The S-K score was significantly lower in the NR and MN groups than in the AN group $(p<0.001)$. Percent predicted FVC and FEV1 were significantly lower in the MN group than in the AN and NR groups ( $p<0.001$ for both). Fecal elastase-1 levels were significantly lower in the NR group than in the AN and MN groups ( $p<$ 0.001 for both). Fifty-six patients were on pancreatic enzyme replacement therapy, and the number of enzyme units $/ \mathrm{kg} / \mathrm{meal}$ was significantly higher in the MN group than in the AN group ( $<0.001)$ and in the NR group ( $p=0.001)$.

Table 3 shows the self-reported compliance with the high calorie diet, pancreatic enzyme replacement therapy, and vitamin supplementation intake in the three nutritional groups. No significant differences were found among the groups regarding those variables.

The logistic regression analysis identified three independent factors associated with malnutrition: age $(O R=0.78 ; p=0.013), S-K$ score $(O R=0.90 ; p=$ $0.015)$, and $\mathrm{FEV}_{1}$ in \% of the predicted value (OR = $0.95 ; p=0.046$; Table 4).

The ROC curve analyses showed that the area under the curve for the S-K score was 0.85 . Using a cut-off value of $\leq 65$ points as a predictor of malnutrition, we found a sensitivity of $78.8 \%$, a specificity of $67.3 \%$, a positive predictive value of $43.8 \%$, and a negative predictive value of $90.2 \%$. The area under the curve for $\mathrm{FEV}_{1}$ in $\%$ of the predicted value was 0.83 . Using a cut-off value of $\leq 40 \%$ as a predictor of malnutrition, we found a sensitivity of $67.7 \%$, a specificity of $81.8 \%$, a positive predictive value of $54.5 \%$, and a negative predictive value of $88.2 \%$. As for age, the area under the curve was 0.57 . Using a cut-off value of $\leq 22$ years of age as a predictor of malnutrition, we found a sensitivity of $50.0 \%$, a specificity of $58.2 \%$, a positive predictive value of $28.1 \%$, and a negative predictive value of $78.1 \%$.

\section{DISCUSSION}

The current cross-sectional study provided relevant information about the prevalence of malnutrition and the clinical characteristics associated with malnutrition in CF patients attending an adult program at a large tertiary care center in southern Brazil. First, half of the patients presented adequate nutrition, and one-fourth was malnourished. Second, we identified some independent factors associated with the risk of malnutrition: S-K score, $\mathrm{FEV}_{1}$ in \% of the predicted value, and age. Therefore, our findings contribute to raising the awareness of the multifactorial aspects of malnutrition in adolescent and adult patients with CF. In an attempt to improve nutrition in clinical practice, the CF multidisciplinary team should take into account patients at a younger age, with low clinical scores and with impaired pulmonary function. 
Table 2. Comparison of clinical characteristics among the study groups. ${ }^{a}$

\begin{tabular}{|c|c|c|c|c|}
\hline \multirow[t]{3}{*}{ Variable } & \multicolumn{3}{|c|}{ Group } & \multirow[t]{3}{*}{$\mathbf{p}$} \\
\hline & $\begin{array}{l}\text { Adequate } \\
\text { nutrition }\end{array}$ & Nutritional risk & Malnutrition & \\
\hline & $(n=32)$ & $(n=23)$ & $(n=18)$ & \\
\hline \multicolumn{5}{|l|}{ Gender } \\
\hline Male & $11(34.4)$ & $12(52.2)$ & $10(55.6)$ & 0.254 \\
\hline Female & $21(65.6)$ & $11(47.8)$ & $8(44.4)$ & \\
\hline Age, years & $25.8 \pm 8.8$ & $26.7 \pm 6.2$ & $23.8 \pm 5.5$ & 0.454 \\
\hline Age at diagnosis, years ${ }^{\mathrm{b}}$ & $12.0(18.0)$ & $4.0(8.0)$ & $9.5(18.0)$ & 0.043 \\
\hline S-K score & $79.5 \pm 12.1^{\mathrm{A}}$ & $70.6 \pm 10^{B}$ & $53.9 \pm 17.0^{c}$ & $<0.001$ \\
\hline \multicolumn{5}{|l|}{ Type of mutation } \\
\hline Homozygous for F508del & $5(15.6)$ & $3(13.0)$ & $5(27.8)$ & 0.326 \\
\hline Heterozygous for F508del & $13(40.6)$ & $10(43.5)$ & $10(55.6)$ & \\
\hline Other/unidentified mutations & $14(43.8)$ & $10(43.5)$ & $3(16.7)$ & \\
\hline \multicolumn{5}{|l|}{ Liver score } \\
\hline Normal & $24(75.0)$ & 17 (73.9) & $12(66.7)$ & 0.806 \\
\hline Abnormal & $8(25.0)$ & $6(26.1)$ & $6(33.3)$ & \\
\hline CFRD & $1(3.1)$ & $7(30.4)$ & $2(11.1)$ & 0.014 \\
\hline \multicolumn{5}{|l|}{ Lung function } \\
\hline FVC, L & $3.4 \pm 1.2^{\mathrm{A}}$ & $3.0 \pm 1.1^{\mathrm{AB}}$ & $2.2 \pm 1.1^{\mathrm{B}}$ & 0.002 \\
\hline FVC, \% predicted & $83.9 \pm 32.3^{\mathrm{A}}$ & $73.1 \pm 25.5^{A}$ & $46.7 \pm 23.0^{B}$ & $<0.001$ \\
\hline $\mathrm{FEV}_{1}, \mathrm{~L}$ & $2.5 \pm 1.0^{\mathrm{A}}$ & $2.1 \pm 1.0^{\mathrm{A}}$ & $1.3 \pm 0.7^{\mathrm{B}}$ & $<0.001$ \\
\hline $\mathrm{FEV}_{1}, \%$ predicted & $74.2 \pm 30.8^{A}$ & $58.9 \pm 25.9^{A}$ & $35.0 \pm 18.1^{\mathrm{B}}$ & $<0.001$ \\
\hline \multicolumn{5}{|l|}{ Fecal elastase- 1 test classification ${ }^{c}$} \\
\hline Moderate pancreatic insufficiency $(100-200 \mu \mathrm{g} / \mathrm{g})$ & $17(56.7)$ & $6(28.6)^{*}$ & $13(86.7)^{*}$ & 0.002 \\
\hline Severe pancreatic insufficiency $(<100 \mu \mathrm{g} / \mathrm{g})$ & $13(43.3)$ & $15(71.4)^{*}$ & $2(13.3)^{*}$ & \\
\hline Fecal elastase-1, $\mu \mathrm{g} / \mathrm{g}$ & $94.0 \pm 32.6^{A}$ & $70.8 \pm 35.4^{B}$ & $119.2 \pm 28.9^{c}$ & $<0.001$ \\
\hline \multicolumn{5}{|l|}{ Bacterial colonization } \\
\hline Pseudomonas aeruginosa & $20(62.5)$ & $16(69.6)$ & $12(66.7)$ & 0.858 \\
\hline Staphylococcus aureus & $22(68.8)$ & $14(60.9)$ & $14(77.8)$ & 0.512 \\
\hline MRSA & $1(3.1)$ & $4(17.4)$ & $3(16.7)$ & 0.166 \\
\hline Burkholderia cepacia & $6(18.8)$ & $6(26.1)$ & $3(16.7)$ & 0.718 \\
\hline Enzyme units of lipase $/ \mathrm{kg} /$ meal & $725.0 \pm 476.4^{A}$ & $830.2 \pm 456.9^{A}$ & $1423.9 \pm 404.3^{B}$ & $<0.001$ \\
\hline
\end{tabular}

S-K: Shwachman-Kulczycki; CFRD: cystic fibrosis-related diabetes; and MRSA: methicillin-resistant Staphylococcus aureus. ${ }^{a}$ Values expressed as $\mathrm{n}(\%)$ or mean $\pm \mathrm{SD}$, except where otherwise indicated. ${ }^{b}$ Values expressed as median (interquartile range). ${ }^{c} n=66$. *Adjusted standard residual $>1.96$ or $<-1.96$ implies significantly different percentages. One-way ANOVA with Tukey's post hoc test and Kruskal-Wallis with post-hoc Z test: the means or medians were significantly different when subscript letters $(A, B$, and $C$ ) are different (chi-square test for categorical variables).

To discuss nutritional status is challenging, since authors use different parameters to assess it. Moreover, the definition of malnutrition varies in the literature. Although guidelines recommend BMI as a simple anthropometric indicator to classify nutritional status with the purpose of improving nutritional care for CF patients, the use of multiple and appropriate nutritional indicators could be of great importance to improve care for individual patients in CF health care practices. $(7,14,19,20)$

The proportion of CF patients with malnutrition in the present study (24.7\%) is similar to findings reported in other studies. ${ }^{(21-24)}$ A cross-sectional study conducted in Greece $^{(21)}$ and using the same methodology and the same cut-off points in order to classify nutritional status showed that $23 \%$ of 68 patients with CF were malnourished. However, that study involved 37 children and adolescents. ${ }^{(21)}$ In contrast, a study carried out in an adult tertiary CF center in France with 163 patients showed that $49.7 \%$ of the patients suffered from malnutrition. ${ }^{(22)}$ That study also used the same methodology and the same cut-off points for classifying malnutrition. (22) A retrospective cross-sectional study conducted in São Paulo, Brazil, and involving 30 adolescents (in the 10.1- to 19.8-year age bracket), using a different methodology (BMI for age) to evaluate their nutritional status. ${ }^{(23)}$ The cut-off points were the following: $\geq z$-score -3 and $<z$-score -2 (thinness); z-score -2 and $\leq$ z-score +1 (normal weight); and $>$ z-score +1 (overweight or obesity). The median (minimum; maximum) BMI-for-age $z$-score was -0.6 $(-3.7 ;+2.6)$, which corresponds to adequate nutritional status in accordance with the World Health Organization parameters. ${ }^{(23)}$ In 2007, a previous study conducted in our hospital included 41 CF patients (16-47 years of age), used the same methodology and the same cut-off 
Table 3. Self-reported adherence to a high-calorie diet, pancreatic enzyme replacement therapy, and vitamin supplementation intake, by group.

\begin{tabular}{|c|c|c|c|c|}
\hline \multirow[t]{2}{*}{ Variable } & \multicolumn{3}{|c|}{ Group } & \multirow[t]{2}{*}{$\mathbf{p}$} \\
\hline & Adequate nutrition & Nutritional risk & Malnutrition & \\
\hline \multicolumn{5}{|l|}{ High-calorie diet } \\
\hline High & $25(78.1)$ & $15(65.2)$ & $10(55.6)$ & 0.49 \\
\hline Moderate & $4(12.5)$ & $6(26.1)$ & $5(27.8)$ & \\
\hline Low & $3(9.4)$ & $2(8.7)$ & $3(16.7)$ & \\
\hline \multicolumn{5}{|c|}{ Pancreatic enzyme replacement therapy ${ }^{a}$} \\
\hline High & $15(93.8)$ & $20(87.0)$ & $15(88.2)$ & 0.33 \\
\hline Moderate & $0(0.0)$ & $3(13.0)$ & $2(11.8)$ & \\
\hline Low & $1(6,3)$ & $0(0.0)$ & $0(0.0)$ & \\
\hline \multicolumn{5}{|l|}{ Vitamin supplementation ${ }^{\mathrm{b}}$} \\
\hline High & $17(89.5)$ & $20(87.0)$ & $16(94.1)$ & 0.816 \\
\hline Moderate & $1(5.3)$ & $1(4.3)$ & $1(5.9)$ & \\
\hline Low & $1(5.3)$ & $2(8.7)$ & $0(0.0)$ & \\
\hline
\end{tabular}

${ }^{a} \mathrm{n}=56$; pancreatic enzyme replacement therapy not indicated in 17 patients. ${ }^{\mathrm{b}} \mathrm{n}=59$ : vitamin supplementation not indicated in 14 patients.

Table 4. Logistic regression analysis (enter method) for malnutrition.

\begin{tabular}{lcccc}
\multicolumn{1}{c}{ Variable } & Beta & $\mathbf{p}$ & OR & 95\% Cl for OR \\
Male gender & -0.41 & 0.961 & 0.96 & $0.19-4.95$ \\
Age & -0.24 & 0.013 & 0.78 & $0.65-0.95$ \\
S-K score & -0.11 & 0.015 & 0.90 & $0.82-0.98$ \\
FEV $_{1}, \%$ predicted & -0.05 & 0.046 & 0.95 & $0.90-0.99$ \\
Constant & 14.65 & 0.002 & $2,312,450.04$ & - \\
\hline
\end{tabular}

S-K: Shwachman-Kulczycki.

point for malnutrition, and identified 9 malnourished patients (22\%). ${ }^{(24)}$ These remarkable discrepancies in the prevalence of malnutrition in CF patients can be attributed to the heterogeneity of the disease, the survival effect observed in cohorts of adult subjects, interpopulation variations, and differences in quality of health care or in study design (sample selection, age groups included, indicators of malnutrition, and cut-off values).

The association between nutritional status and lung function has been long recognized. Numerous studies have noted the negative effect of malnutrition on respiratory function and prognosis. ${ }^{(25,26)}$ The results of the present study confirm that nutrition and lung function are codependent variables in CF patients, poor lung function being predictive of malnutrition. In a recent study, Hulzebos et al. (27) showed that the use of BMI combined with $\mathrm{FEV}_{1}$ could accurately predict mortality in CF patients. Another recent study with 14,732 patients ( $\geq 6$ years of age) from the European Cystic Fibrosis Society Patient Registry confirmed that poor BMI was significantly associated with poor lung function. (28) The authors emphasized that BMI is a preventable or potentially treatable factor; however, despite the available guidelines for the prevention and correction of nutritional deficiencies in $\mathrm{CF}, 9.5 \%$ of the patients with $\mathrm{CF}$ in Europe still suffer from chronic severe malnutrition. ${ }^{(28)}$

Exocrine pancreatic insufficiency has been found to be a prognostic factor for malnutrition. Couper et al.,(29) in a longitudinal study, showed that patients with pancreatic sufficiency developed pancreatic insufficiency at an older age. In the current study, the fecal elastase- 1 test was used in order to quantify the severity of pancreatic insufficiency and to predict malnutrition. All of the patients in our sample had levels of fecal elastase $-1<200 \mu \mathrm{g} / \mathrm{g}$. Surprisingly, fecal elastase-1 levels were higher in the MN group than in the AN group, as well as being higher in the AN group than in the NR group. One possible explanation for this finding is that the differences in mean levels of fecal elastase-1 among the groups, although statistically significant, were of low magnitude and did not impact on the nutritional outcome.

Another finding in the present study was that the malnourished patients were treated with significantly higher pancreatic enzyme replacement dosing than were those in the other groups. This finding contrasts with a recent retrospective analysis by Haupt et al., ${ }^{\left({ }^{30}\right)}$ who suggested that pancreatic enzyme replacement dosing is associated with better nutritional status; however, that study included children only. The mean enzyme replacement dosing in our patients was in agreement with recommendations of the guidelines ${ }^{(7)}$ : not greater than 2,500 lipase units $/ \mathrm{kg} / \mathrm{meal}$.

The S-K score ${ }^{(15)}$ is a general clinical severity score with four domains: general activity, physical examination, nutrition, and radiological findings. Each domain ranges from 0 to 25 points, and the domain scores are added to give the overall score (up to 100). Higher scores 
reflect better clinical status. In the current study, low clinical scores were predictive of malnutrition. The S-K score was not used in three previous studies of the nutritional status in CF patients. ${ }^{(21-23)}$ In contrast, there was no significant association between malnutrition and the S-K score in the study by Ziegler et al.(24)

Longitudinal studies have demonstrated that malnutrition can be expected to increase with aging. (31,32) $^{2}$ However, it is interesting that our results showed that young age was a predictor of malnutrition only in the multivariable analysis. Nevertheless, it is likely that age and the preservation of nutritional status are related to milder disease, and that a later onset of the disease has a positive impact on the nutritional status of the patients. One hypothesis for this finding is the survival bias in the present CF population. Patients with poor lung function and malnutrition did not reach the age range under consideration in the present study.

In our study, the self-reported compliance with a high calorie diet, pancreatic enzyme replacement therapy, and vitamin supplementation intake was high and was not associated with the nutritional status. In a previous study, ${ }^{(33)} 65.8 \%, 96.3 \%$, and $79.4 \%$ of the patients, respectively, self-reported good compliance with a highcalorie diet, pancreatic enzyme replacement therapy, and vitamin supplementation intake. Arias Llorente et al. ${ }^{(34)}$ suggested that patients would be more compliant with their treatment if they believed it to be beneficial and to improve their quality of life. Moreover, previous studies demonstrated that patients who understand the importance of following medical instructions and trust their physicians are probably more compliant. The fact that treatment adherence tends to diminish with age has also been mentioned. ${ }^{(18,35)}$

The present study has potential limitations. Because it was a cross-sectional study, it was impossible to establish the temporal sequence of the factors studied and malnutrition. In addition, our sample of patients was also small.

In conclusion, the present study has demonstrated that malnutrition remains a common complication in adolescents and adults with $\mathrm{CF}$, despite dietary advice. Malnutrition is associated with age, clinical severity, and lung function impairment.

\section{REFERENCES}

1. Madan JC, Koestler DC, Stanton BA, Davidson L, Moulton LA Housman $\mathrm{ML}$, et al. Serial analysis of the gut and respiratory microbiome in cystic fibrosis in infancy: interaction between intestinal and respiratory tracts and impact of nutritional exposures. MBio. 2012;3(4):e00251-12. pii: e00251-12.

2. Davies JC, Alton EW, Bush A. Cystic fibrosis. BMJ. 2007;335(7632):1255-9. https://doi.org/10.1136/bmj.39391.713229. $\mathrm{AD}$

3. Cohen-Cymberknoh M, Shoseyov D, Kerem E. Managing cystic fibrosis: strategies that increase life expectancy and improve quality of life. Am J Respir Crit Care Med. 2011;183(11):1463-71. https://doi. org/10.1164/rccm.201009-1478Cl

4. Strausbaugh SD, Davis PB. Cystic fibrosis: a review of epidemiology and pathobiology. Clin Chest Med. 2007;28(2):279-88. https://doi. org/10.1016/j.ccm.2007.02.011

5. Boyle MP. Adult cystic fibrosis. JAMA. 2007;298(15):1787-93 https://doi.org/10.1001/jama.298.15.1787

6. Milla CE. Nutrition and lung disease in cystic fibrosis. Clin Chest Med 2007;28(2):319-30. https://doi.org/10.1016/j.ccm.2007.02.006

7. Stallings VA, Stark LJ, Robinson KA, Feranchak AP, Quinton $H$ Clinical Practice Guidelines on Growth and Nutrition Subcommittee et al. Evidence-based practice recommendations for nutritionrelated management of children and adults with cystic fibrosis and pancreatic insufficiency: results of a systematic review. J Am Diet Assoc. 2008;108(5):832-9. https://doi.org/10.1016/j.jada.2008.02.020

8. Peterson ML, Jacobs DR Jr, Milla CE. Longitudinal changes in growth parameters are correlated with changes in pulmonary function in children with cystic fibrosis. Pediatrics. 2003; 112(3 Pt 1):588-92. https://doi.org/10.1542/peds.112.3.588

9. Konstan MW, Butler SM, Wohl ME, Stoddard M, Matousek R Wagener JS, et al. Growth and nutritional indexes in early life predict pulmonary function in cystic fibrosis. J Pediatr. 2003;142(6):624-30 https://doi.org/10.1067/mpd.2003.152

10. Ranganathan SC, Parsons F, Gangell C, Brennan S, Stick SM, Sly $P D$, et al. Evolution of pulmonary inflammation and nutritional status in infants and young children with cystic fibrosis. Thorax. 2011;66(5):408-13. https://doi.org/10.1136/thx.2010.139493

11. Sheikh S, Zemel BS, Stallings VA, Rubenstein RC, Kelly A. Body composition and pulmonary function in cystic fibrosis. Front Pediatr. 2014;2:33. https://doi.org/10.3389/fped.2014.00033

12. Rosenstein BJ, Cutting GR. The diagnosis of cystic fibrosis: a consensus statement. Cystic Fibrosis Foundation Consensus Panel. J Pediatr. 1998;132(4):589-95. https://doi.org/10.1016/S00223476(98)70344-0
13. Williams SG, Evanson JE, Barrett N, Hodson ME, Boultbee JE, Westaby D. An ultrasound scoring system for the diagnosis of liver disease in cystic fibrosis. J Hepatol. 1995;22(5):513-21. https://doi. org/10.1016/0168-8278(95)80444-7

14. Borowitz D, Baker RD, Stallings V. Consensus report on nutrition for pediatric patients with cystic fibrosis. J Pediatr Gastroenterol Nutr. 2002;35(3):246-59. https://doi.org/10.1097/00005176-20020900000004

15. Shwachman H, Kulczychi L. Long-term study of one hundred five patients with cystic fibrosis; studies made over a five- to fourteen-year period. AMA J Dis Child. 1958;96(1):6-15. https://doi. org/10.1001/archpedi.1958.02060060008002

16. Pereira CA, Barreto SP, Simões JG, Pereira FW, Gerstler JG Nakatani J. Valores de referência para espirometria em uma amostra da população brasileira adulta. J Pneumol. 1992;18(1):10-22.

17. Löser C, Möllgaard A, Fölsch UR. Faecal elastase 1: a novel, highly sensitive, and specific tubeless pancreatic function test. Gut. 1996;39(4):580-6. https://doi.org/10.1136/gut.39.4.580

18. Conway SP, Pond MN, Hamnett T, Watson A. Compliance with treatment in adult patients with cystic fibrosis. Thorax. 1996;51(1):29 33. https://doi.org/10.1136/thx.51.1.29

19. Sinaasappel M, Stern M, Littlewood J, Wolfe S, Steinkamp G, Heijerman $\mathrm{HG}$, et al. Nutrition in patients with cystic fibrosis: a European Consensus. J Cyst Fibros. 2002;1(2):51-75. https://doi. org/10.1016/S1569-1993(02)00032-2

20. Yankaskas JR, Marshall BC, Sufian B, Simon RH, Rodman D. Cystic fibrosis adult care: consensus conference report. Chest. 2004;125(1 Suppl):1S-39S. https://doi.org/10.1378/chest.125.1_suppl.1S

21. Panagopoulou $P$, Fotoulaki M, Nikolaou A, Nousia-Arvanitakis S Prevalence of malnutrition and obesity among cystic fibrosis patients. Pediatr Int. 2014;56(1):89-94. https://doi.org/10.1111/ped.12214

22. Dray $X$, Kanaan $R$, Bienvenu $T$, Desmazes-Dufeu N, Dusser D, Marteau $\mathrm{P}$, et al. Malnutrition in adults with cystic fibrosis. Eur J Clin Nutr. 2005;59(1):152-4. https://doi.org/10.1038/sj.ejcn.1602039

23. Del Ciampo IR, Del Ciampo LA, Sawamura R, de Oliveira LR Fernandes MI. Nutritional status of adolescents with cystic fibrosis treated at a reference center in the southeast region of Brazil. Ital $J$ Pediatr. 2015;41:51. https://doi.org/10.1186/s13052-015-0159-x

24. Ziegler B, Rovedder PM, Lukrafka JL, Abrahão CL, Dalcin PT. Estado nutricional em pacientes atendidos por um programa de adultos para fibrose cística. Rev HCPA. 2007;27(3):13-9.

25. Corey M, McLaughlin FJ, Williams M, Levison H. A comparison of survival, growth, and pulmonary function in patients with cystic fibrosis in Boston and Toronto. J Clin Epidemiol. 1988;41(6):583-91. 
https://doi.org/10.1016/0895-4356(88)90063-7

26. Zemel BS, Jawad AF, FitzSimmons S, Stallings VA. Longitudinal relationship among growth, nutritional status, and pulmonary function in children with cystic fibrosis: analysis of the Cystic Fibrosis Foundation National CF Patient Registry. J Pediatr. 2000;137(3):37480. https://doi.org/10.1067/mpd.2000.107891

27. Hulzebos $E H$, Bomhof-Roordink $H$, van de Weert-van Leeuwen $\mathrm{PB}$, Twisk JW, Arets $\mathrm{HG}$, van der Ent CK, et al. Prediction of mortality in adolescents with cystic fibrosis. Med Sci Sports Exerc. 2014;46(11):2047-52. https://doi.org/10.1249/ MSS. 0000000000000344

28. Kerem E, Viviani L, Zolin A, MacNeill S, Hatziagorou E, Ellemunter $H$, et al. Factors associated with FEV1 decline in cystic fibrosis: analysis of the ECFS patient registry. Eur Respir J. 2014;43(1):125-33. https:// doi.org/10.1183/09031936.00166412

29. Couper RT, Corey M, Moore DJ, Fisher LJ, Forstner GG, Durie PR, Decline of exocrine pancreatic function in cystic fibrosis patients with pancreatic sufficiency. Pediatr Res. 1992;32(2):179-82. https://doi. org/10.1203/00006450-199208000-00011

30. Haupt ME, Kwasny MJ, Schechter MS, McColley SA. Pancreatic enzyme replacement therapy dosing and nutritional outcomes in children with cystic fibrosis. J Pediatr. 2014;164(5):1110-1115.e1. https://doi.org/10.1016/j.jpeds.2014.01.022

31. Steinkamp G. Wiedemann B. Relationship between nutritional status and lung function in cystic fibrosis: cross sectional and longitudina analyses from the German CF quality assurance (CFOA) project. Thorax. 2002;57(7):596-601. https://doi.org/10.1136/thorax.57.7.596

32. Nir M, Lanng $S$, Johansen HK, Koch C. Long-term survival and nutritional data in patients with cystic fibrosis treated in a Danish centre. Thorax. 1996;51(10):1023-7. https://doi.org/10.1136/ thx.51.10.1023

33. Dalcin Pde T, Rampon G, Pasin LR, Ramon GM, Abrahão CL, Oliveira VZ. Adherence to treatment in patients with cystic fibrosis [Article in Portuguese]. J Bras Pneumol. 2007;33(6):663-70.

34. Arias Llorente RP, Bousoño García C, Díaz Martín JJ. Treatment compliance in children and adults with cystic fibrosis. J Cyst Fibros. 2008;7(5):359-67. https://doi.org/10.1016/j.jcf.2008.01.003

35. Abbott J, Dodd M, Gee L, Webb K. Ways of coping with cystic fibrosis: implications for treatment adherence. Disabil Rehabil. 2001;23(8):315-24. https://doi.org/10.1080/0963828001000417 